\title{
Metabolic and transcriptome responses of RNAi-mediated AMPKa knockdown in Tribolium castaneum
}

\author{
Heng Jiang ${ }^{1}$, Nan Zhang ${ }^{1}$, Caihong Ji ${ }^{1}$, Xiangkun Meng ${ }^{1}$, Kun Qian ${ }^{1}$, Yang Zheng ${ }^{1}$ and Jianjun Wang ${ }^{1,2^{*}}$
}

\begin{abstract}
Background: The AMP-activated protein kinase (AMPK) is an intracellular fuel sensor for lipid and glucose metabolism. In addition to the short-term regulation of metabolic enzymes by phosphorylation, AMPK may also exert long-term effects on the transcription of downstream genes through the regulation of transcription factors and coactivators. In this study, RNA interference (RNAi) was conducted to investigate the effects of knockdown of TCAMPKa on lipid and carbohydrate metabolism in the red flour beetle, Tribolium castaneum, and the transcriptome profiles of dsTCAMPKa-injected and dsEGFP-injected beetles under normal conditions were compared by RNAsequencing.

Results: RNAi-mediated suppression of TCAMPKa increased whole-body triglyceride (TG) level and the ratio between glucose and trehalose, as was confirmed by in vivo treatment with the AMPK-activating compound, 5Aminoimidazole-4-carboxamide1- $\beta$-D-ribofuranoside (AICAR). A total of 1184 differentially expressed genes (DEGs) were identified between dsTCAMPKa-injected and dsEGFP-injected beetles. These include genes involved in lipid and carbohydrate metabolism as well as insulin/insulin-like growth factor signaling (IIS). Real-time quantitative polymerase chain reaction analysis confirmed the differential expression of selected genes. Interestingly, metabolism-related transcription factors such as sterol regulatory element-binding protein 1 (SREBP1) and carbohydrate response element-binding protein (ChREBP) were also significantly upregulated in dsTcAMPKainjected beetles.

Conclusions: AMPK plays a critical role in the regulation of beetle metabolism. The findings of DEGs involved in lipid and carbohydrate metabolism provide valuable insight into the role of AMPK signaling in the transcriptional regulation of insect metabolism.
\end{abstract}

Keywords: Tribolium castaneum, AMPK, RNA interference, Transcriptome, Lipid metabolism, Carbohydrate metabolism IIS pathway

\footnotetext{
* Correspondence: wangjj@yzu.edu.cn

${ }^{1}$ College of Horticulture and Plant Protection, Yangzhou University, Yangzhou 225009, China

2Joint International Research Laboratory of Agriculture and Agri-Product Safety of the Ministry of Education, Yangzhou University, Yangzhou 225009, China
}

(c) The Author(s). 2020 Open Access This article is licensed under a Creative Commons Attribution 4.0 International License, which permits use, sharing, adaptation, distribution and reproduction in any medium or format, as long as you give appropriate credit to the original author(s) and the source, provide a link to the Creative Commons licence, and indicate if changes were made. The images or other third party material in this article are included in the article's Creative Commons licence, unless indicated otherwise in a credit line to the material. If material is not included in the article's Creative Commons licence and your intended use is not permitted by statutory regulation or exceeds the permitted use, you will need to obtain permission directly from the copyright holder. To view a copy of this licence, visit http://creativecommons.org/licenses/by/4.0/ The Creative Commons Public Domain Dedication waiver (http://creativecommons.org/publicdomain/zero/1.0/) applies to the data made available in this article, unless otherwise stated in a credit line to the data. 


\section{Background}

The survival of all organisms depends on the maintenance of energy homeostasis. AMP-activated protein kinase (AMPK) is a cellular energy sensor conserved across all eukaryotic species [13]. As a serine/threonine protein kinase complex, AMPK consists of a catalytic subunit $\alpha$ and two regulatory subunits, $\beta$ and $\gamma$, and is activated in response to energy stress by sensing increases in ADP/ ATP and AMP/ATP ratios, which leads to the activation of ATP-generating catabolic pathways including glycolysis and fatty acid oxidation and the inhibition of ATPconsuming anabolic pathways such as gluconeogenesis, fatty acid and protein synthesis [17]. While nucleotidedependent phosphorylation of Thr172 in the $\alpha$ subunit by liver kinase B1 (LKB1) is the principal event required for full activation of AMPK in mammalian cells [19, 70], several studies have revealed the nucleotide-independent regulation of AMPK via the phosphorylation of Thr172 by calcium/calmodulin-dependent kinase kinase 2 in mammals (CAMKK2) [20, 23, 69].

Lipids and carbohydrates are major sources for energy storage and supply in cells. Under aerobic conditions, most energy is derived from fatty acids oxidation and the rest of energy is obtained from glucose oxidation. In contrast, glycolysis plays an important role in ATP production under anoxic condition [51]. Activation of AMPK occurs in response to stress circumstances such as starvation, exercise, hypoxia and ischemia, heat shock, and oxidative stress $[9,11,18,45,47,49,67]$. It is well known that AMPK can regulate lipid and carbohydrate homeostasis via direct phosphorylation of multiple downstream effectors. Acetyl-CoA carboxylase (ACC), the first rate-limiting enzyme in fatty acid synthesis, glycerol-3phosphate acyltransferases (GPAT), the rate-limiting enzyme in triglyceride (TG) synthesis, and 3-hydroxy-3methylglutaryl-CoA reductase (HMGR), the rate-limiting enzyme of cholesterol biosynthesis pathway, can be inhibited by AMPK through phosphorylation in rats $[8,42,68]$. Subsequently, AMPK was found to promote lipid absorption and release by directly phosphorylating lipases like hormone-sensitive lipase (HSL) and adipocytetriglyceride lipase (ATGL) in mice and Caenorhabditis elegans [1, 44, 64]. On the other hand, AMPK also stimulates glycolysis via the phosphorylation and activation of 6-phosphofructo-2-kinase/fructose-2,6-biphosphatase 3 (PFKFB3) and 6-phosphofructo-2-kinase (PFK2) in human tissues [37, 38]. Additionally, AMPK activation was also shown to increase whole-body insulin sensitivity by phosphorylation of insulin receptor substrate-1 (IRS-1) in mouse [24] and insulin receptor (InR) in rodent muscle [10]. Given the functional attributes of AMPK in lipid and carbohydrate metabolism, AMPK is considered as an important therapeutic target for treating metabolic diseases including obesity and type 2 diabetes [43].
Although the role of AMPK in the regulation of cell metabolism is well studied in mammals, related research is still limited in insects. Notably, AMPK can regulate energy balance via modulation of transcriptional expression of metabolic enzymes in the long term, however, its downstream transcriptional pathways remains largely elusive [7]. Recently, we reported the transcriptional and post-translational activation of TcAMPK $\alpha$ by oxidative, heat and cold stresses in the red flour beetle, Tribolium castaneum [25]. In this study, RNAi was employed to determine the roles of TcAMPK $\alpha$ in lipid and carbohydrate metabolism. Comparison, annotation and classification of DEGs between dsTcAMPK $\alpha$ treatment and control groups were also conducted by high-throughput transcriptome sequencing to identify metabolism-related genes modulated by AMPK in T. castaneum.

\section{Results}

Effects of TCAMPKa suppression on TG, glucose and trehalose levels

RNAi was conducted to determine the effects of TcAMPKa knockdown on TG, glucose and trehalose levels. The injection of 20-day-old larvae with dsTcAMPK $\alpha$ reduced transcription levels by $95.50 \% \pm$ $1.86 \%\left(\right.$ ANOVA, $\mathrm{df}_{2,4}, \mathrm{~F}=97.506, P$ value $\left.=0.0027\right)$ on the sixth day after injection. TG measurement showed that the TG level in dsTcAMPK $\alpha$ group $(9.03 \pm 0.76$ $\mathrm{mmol} / \mathrm{mgprot}$ ) was significantly increased by $53.49 \% \pm$ $8.61 \%$ (ANOVA, $\mathrm{df}_{1,4}, \mathrm{~F}=7.917, P$ value $=0.04813$ ) when compared with the dsEGFP group $(5.96 \pm 0.78$ $\mathrm{mmol} / \mathrm{mgprot}$ ) (Fig. 1a).

Similarly, increased glucose level by $62.34 \% \pm 11.61 \%$ (ANOVA, $\mathrm{df}_{1,4}, \mathrm{~F}=8.196, P$ value $\left.=0.04580\right)$ was observed in the beetles injected with dsTcAMPK $\alpha(25.85 \pm$ $6.12 \mu \mathrm{mol} / \mathrm{g}$ ) when compared to the control beetles $(8.32 \pm 0.08 \mu \mathrm{mol} / \mathrm{g}) \quad$ (Fig. 1b). However, the trehalose level in dsTcAMPK $\alpha$ group $(3.73 \pm 0.10 \mathrm{mg} / \mathrm{g})$ was significantly reduced by $8.56 \% \pm 3.01 \%$ (ANOVA, $\mathrm{df}_{1,4}, \mathrm{~F}=$ 9.357, $P$ value $=0.0377$ ) than that in dsEGFP group $(4.08 \pm 0.05 \mathrm{mg} / \mathrm{g})$ (Fig. 1c). These data suggested that RNAi of TcAMPK $\alpha$ increased TG production and the ratio between glucose and trehalose (Fig. 2a).

\section{Effects of AICAR treatment on TG, glucose and trehalose levels}

To confirm the RNAi results, the 20-day-old larvae were treated with an activator of AMPK 5-Aminoimidazole-4carboxamide1- $\beta$-D-ribofuranoside (AICAR), and the TG, glucose and trehalose levels were measured. The results showed that the levels of TG and glucose in AICAR group were significantly decreased by $34.60 \% \pm 5.74 \%$ (ANOVA, $\mathrm{df}_{1}, 4, \mathrm{~F}=10.770, P$ value $=0.03045$ ) and $41.89 \% \pm 2.27 \%$ (ANOVA, $\mathrm{df}_{1,4}, \mathrm{~F}=93.320, \mathrm{P}$ value $=$ 0.0006), respectively, compared with injection buffer (IB) 


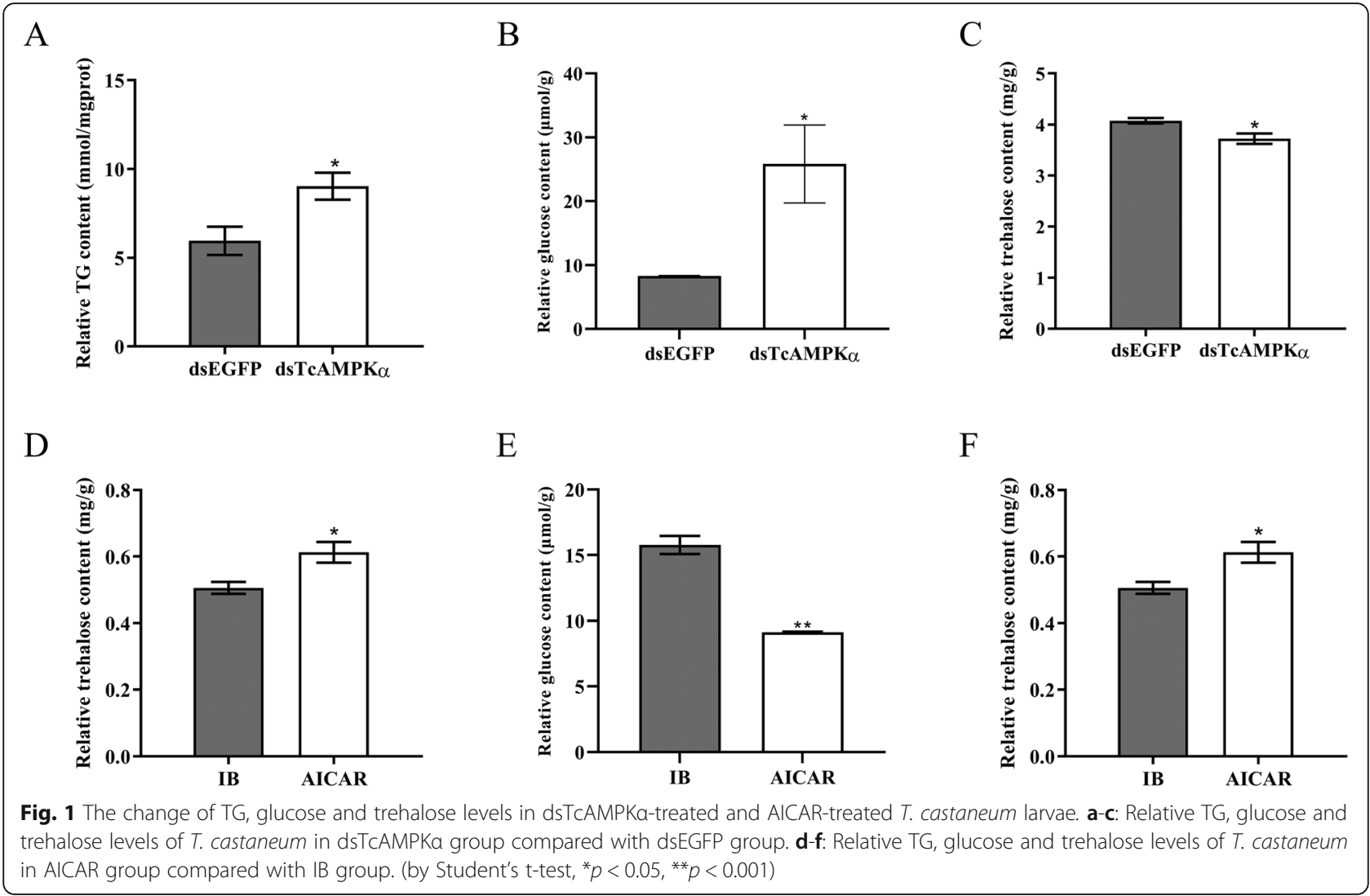

group, whereas the trehalose level increased by $17.07 \% \pm$ $4.02 \%$ (ANOVA, $\mathrm{df}_{1,4}, \mathrm{~F}=8.910, \mathrm{P}$ value $=0.0405$ ) in beetles treated with AICAR. These data suggested that activation of TcAMPK decreased TG production and the ratio between glucose and trehalose (Figs. $1 \mathrm{~d}-\mathrm{f} ; 2 \mathrm{~b}$ ).

\section{Transcriptome sequence and reads mapping}

The dsTcAMPK $\alpha$ and dsEGFP groups were analyzed by RNA-Seq (three independent biological replicates of each treatment). A mean of 23,570,938 clean reads were generated among six independent libraries (T01-T06) (Table 1). Evaluation of clean data quality showed that the GC counts ranged from 42 to $45 \%$ and Q30 ratios were > $93 \%$, indicating a high level of data quality. The alignment of clean reads to the reference genome database of $T$. castaneum showed that 83.50 and $77.15 \%$ reads of the dsEGFP and dsTcAMPK $\alpha$ groups were aligned on average, respectively (Table 2 ).

Correlation analysis was conducted with Pearson's Correlation Coefficient ( $\mathrm{R}$ value) to evaluate the
A

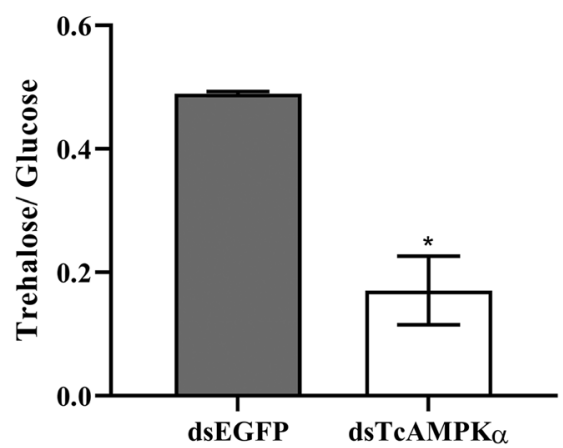

B

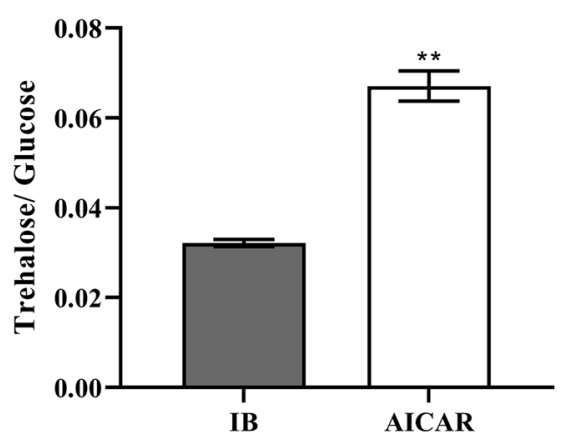

Fig. 2 The ratio between trehalose and glucose under treatment with dsTcAMPKa and AICAR compared with control groups. (by Student's t-test, $\left.{ }^{*} p<0.05,{ }^{* *} p<0.001\right)$ 
Table 1 Summary of the transcriptome sequencing data from the controls and dsTcAMPKa treated samples

\begin{tabular}{llllll}
\hline Samples & ID & $\begin{array}{l}\text { Clean Read } \\
\text { Number }\end{array}$ & $\begin{array}{l}\text { Clean Base } \\
\text { Number }\end{array}$ & GC (\%) & Q30 (\%) \\
\hline EGFP1 & T01 & $21,746,430$ & $6,523,929,000$ & 42.79 & 93.39 \\
EGFP2 & T02 & $20,376,206$ & $6,112,861,800$ & 42.86 & 93.94 \\
EGFP3 & T03 & $26,557,829$ & $7,967,348,700$ & 43.85 & 92.88 \\
dsTCAMPKa1 & T04 & $24,192,194$ & $7,257,658,200$ & 44.91 & 93.25 \\
dsTCAMPKa2 & T05 & $23,215,801$ & $6,964,740,300$ & 45.01 & 92.85 \\
dsTCAMPKa3 & T06 & $25,337,170$ & $7,601,151,000$ & 45.54 & 92.75 \\
\hline
\end{tabular}

biological repeatability based on expression values of each library [52]. The results showed that the Pearson's Correlation Coefficient between the three control samples (T01-T03) was 0.81 , and that of dsTcAMPK $\alpha$ treatment samples (T04-T06) was 0.94 (Fig. 3a). Box plot analysis revealed that the three samples in each group had similar expression distributions of reads, while the control and treatment groups had significantly different expression distributions (Fig. $3 \mathrm{~b}$ ).

Further annotation of expressed unigenes revealed that a total of 14,095 unigenes out of 31,944 unique sequences were annotated and classified into at least one database of Non-redundant (Nr), EuKaryotic Orthologous Groups (KOG), Clusters of Orthologous Groups of proteins (COG), Kyoto Encyclopedia of Genes and Genomes (KEGG), Protein family (Pfam), Gene Ontology (GO) and Swiss-Prot databases (Figure S1, Figure S2 and Table S2).

\section{Changes in gene expression profiles}

To identify the effects of knock-down of TcAMPKa on global unigene expression patterns of $T$. castaneum, DEGs between dsTcAMPK $\alpha$ and dsEGFP groups were identified based on their Fragments Per Kilobase of transcript sequence per Million base pairs sequenced (FPKM) values. 1184 DEGs were obtained including 349 upregulated and 835 downregulated unigenes (Fig. 4a, b and Table S3). The $\log _{2}$-fold variation range of DEGs was between -6.07 and 3.75 (Fold change from -67.18 to $13.45, P$ value from $1.27 \times 10^{-53}$ to 0.04978$)$.

DEGs were classified by searching against GO and KOG databases. GO term enrichments was used to further analyze physiological changes associated with DEGs

Table 2 Summary of average read numbers based on the RNAsequencing data

\begin{tabular}{lll}
\hline & dsTcAMPKa & dsEGFP \\
\hline Total alignments & $38,451,597$ & $39,074,583$ \\
Reads aligned & $37,340,338$ & $37,891,202$ \\
Unique alignments & $36,870,045$ & $37,564,766$ \\
Not aligned & $11,156,438$ & $7,895,775$ \\
\hline
\end{tabular}

in T. castaneum. $\mathrm{GO}$ enrichments revealed that the DEGs involved in cellular component category were enriched in cell part, cell, membrane and organelle (Figure S3). In molecular function category, most of the DEGs were enriched in binding and catalytic activity such as Retrovirus-related Pol polyprotein and ATPase inhibitor, while metabolic and cellular process were the most enriched subcategories in biological process (Figure S3).

KOG database was used to annotate DEGs with specific physiological functions (Fig. 5, Table S4). Although the "General function prediction only" was the most abundant group among all subcategories in KOG database, a large number of DEGs were annotated into the metabolism classifications such as "Lipid transport and metabolism", "Carbohydrate transport and metabolism", "Amino acid transport and metabolism", "Energy production and conversion" and "Secondary metabolites biosynthesis, transport and catabolism" (Table 3). Furthermore, most DEGs involved in protein translation were downregulated such as some ribosomal proteins (Table 3). Similarly, among the 42 DEGs in the posttranslational modification class, 35 DEGs were downregulated, including 3 heat shock proteins (Hsps), whereas the phosphatidylinositol 4,5-bisphosphate 3kinase (PIK3) and InR2 involved in the signal transduction mechanisms were upregulated.

\section{Expression of genes involved in lipid metabolism, carbohydrate metabolism and insulin signaling}

Besides the analysis of the entire gene set, we specifically checked for up- or downregulation of lipid and carbohydrate metabolism genes in our set of DEGs. The results showed that the insect adipose triacylglycerol lipase homologue, brummer (Accession no. TC011935), which is responsible for the first step of TG hydrolysis, was significantly downregulated with the expression $\log _{2}$-fold change of -2.20 (Fold change: 0.22; ANOVA, $\mathrm{df}_{1,4}, \mathrm{~F}=$ $5.152, P$ value $\left.=1.60 \times 10^{-05}\right)$, whereas two fatty acid synthetase genes (FAS1-2) (Accession no. TC015337 and TC015340) (Fold change: 2.03 and 3.22, ANOVA, $\mathrm{df}_{1,4}, \mathrm{~F}=9.182$ and 157.306, $P$ value $=0.03878$ and $0.00023)$ involved in fatty acid biosynthetic pathways, and the transcription factor ChREBP (Accession no. TC010471) (Fold change: 2.27, ANOVA, $\mathrm{df}_{1,}, \mathrm{~F}=$ 96.147, $\mathrm{P}$ value $=0.00061$ ), a key regulator of glucose and lipid metabolism and fat storage [62], were upregulated with the expression $\log _{2}$-fold change from 1.02 to 1.76 (Fold change from 2.03 to 3.39) (Table 4). Knockdown of TcAMPK $\alpha$ also caused upregulation of genes involved in IIS pathway, including PI3K, IRS1 and InR2 (Accession no. TC011996, TC034013 and TC010784) (Fold change: 2.22, 2.19 and 2.46; ANOVA, $\mathrm{df}_{1,4}, \mathrm{~F}=$ $86.102,14.636$ and $34.155, \mathrm{P}$ value $=0.00075,0.01869$ and $\left.3.37 \times 10^{-08}\right)$. To confirm the reliability of the DEG 


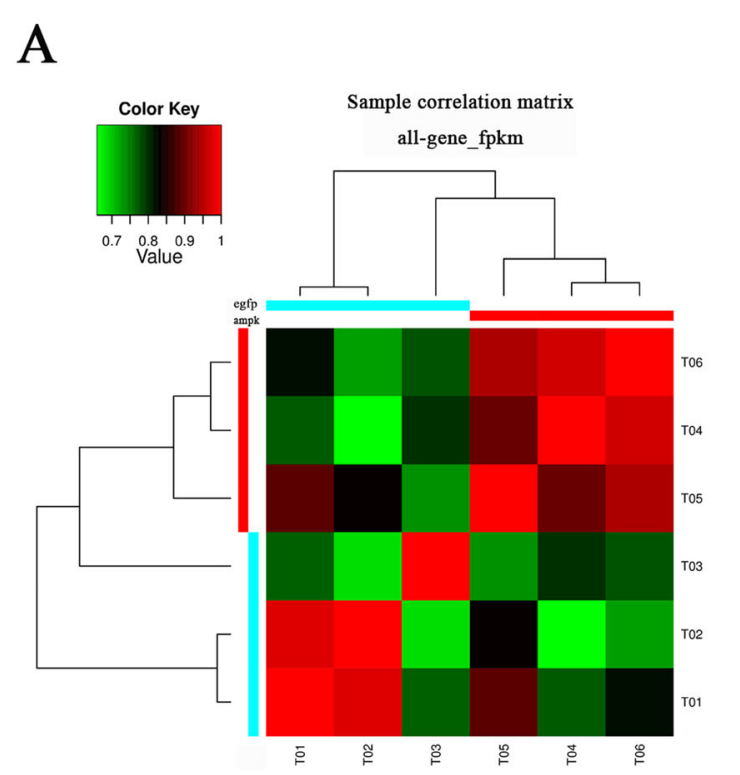

B

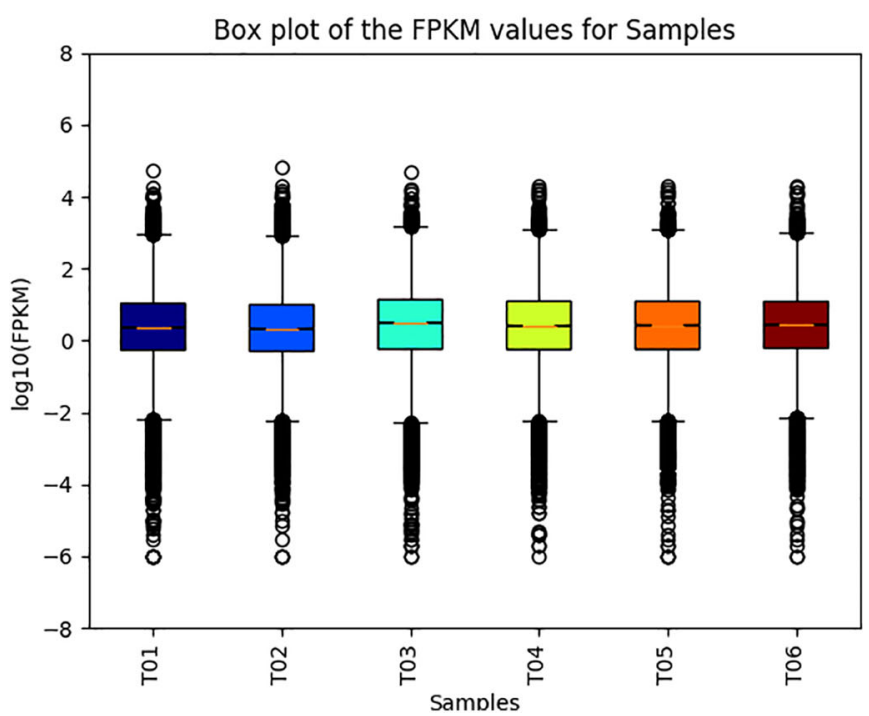

Fig. 3 Correlation and box plot of the gene expression levels (FPKM) for all of the samples. A: Pearson correlations of gene expression levels of the six samples. The higher $\mathrm{R}$ value indicates closer relationship between two samples. B: Box plots of gene expression levels of the six samples. T01-T03 represent control sample (dsEGFP-injected group) libraries, and T04-T06 represent treatment sample (dsAMPKa-injected group) libraries

data, the expression levels of these DEGs were determined using RT-qPCR (Fig. 6 and Table 4). Gene expression levels validated by RT-qPCR showed the high consistency with transcriptome sequencing.

To be as inclusive as possible, less strict screening criteria (Fold change $\mid \log _{2}$ (treatment/control) $\mid>0.5$ ) were applied, and additional lipid and carbohydrate metabolism-related genes with the expression changed in transcriptome were selected for further verification using RT-qPCR. The results showed that five genes involved in fatty acid and triglyceride biosynthetic pathways including three FAS (FAS3-5) (Accession no. TC011522, TC015400 and TC000238) (Fold change: 1.73, 1.55 and 1.50; ANOVA, $\mathrm{df}_{1,4}, \mathrm{~F}=1.717,0.785$ and $2.781, P$ value $=$ $0.26021,0.42567$ and 0.17070 ), one ACC (Accession no. TC015612) (Fold change: 1.77; ANOVA, $\mathrm{df}_{1,4}, \mathrm{~F}=$

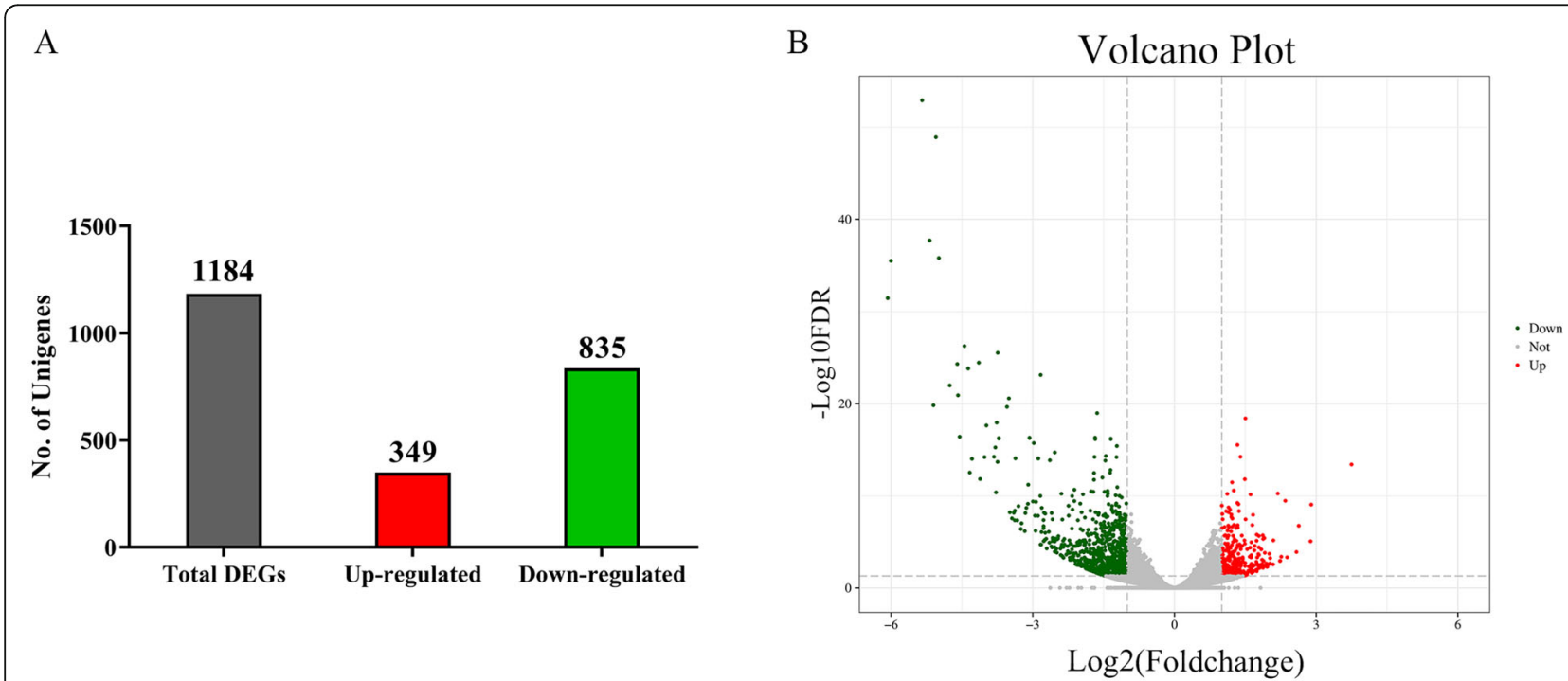

Fig. 4 Differential gene expression analysis of T. castaneum in response to dsTCAMPKa treatment. A: Number of up- and down-regulated DEGs. B: Volcano plot of DEGs. X-axis: $\log _{2}$-fold change (treatment/control). Y-axis: $-\log _{10}$ (FDR). Red data points indicated up-regulated unigenes and green data points indicated down-regulated unigenes 


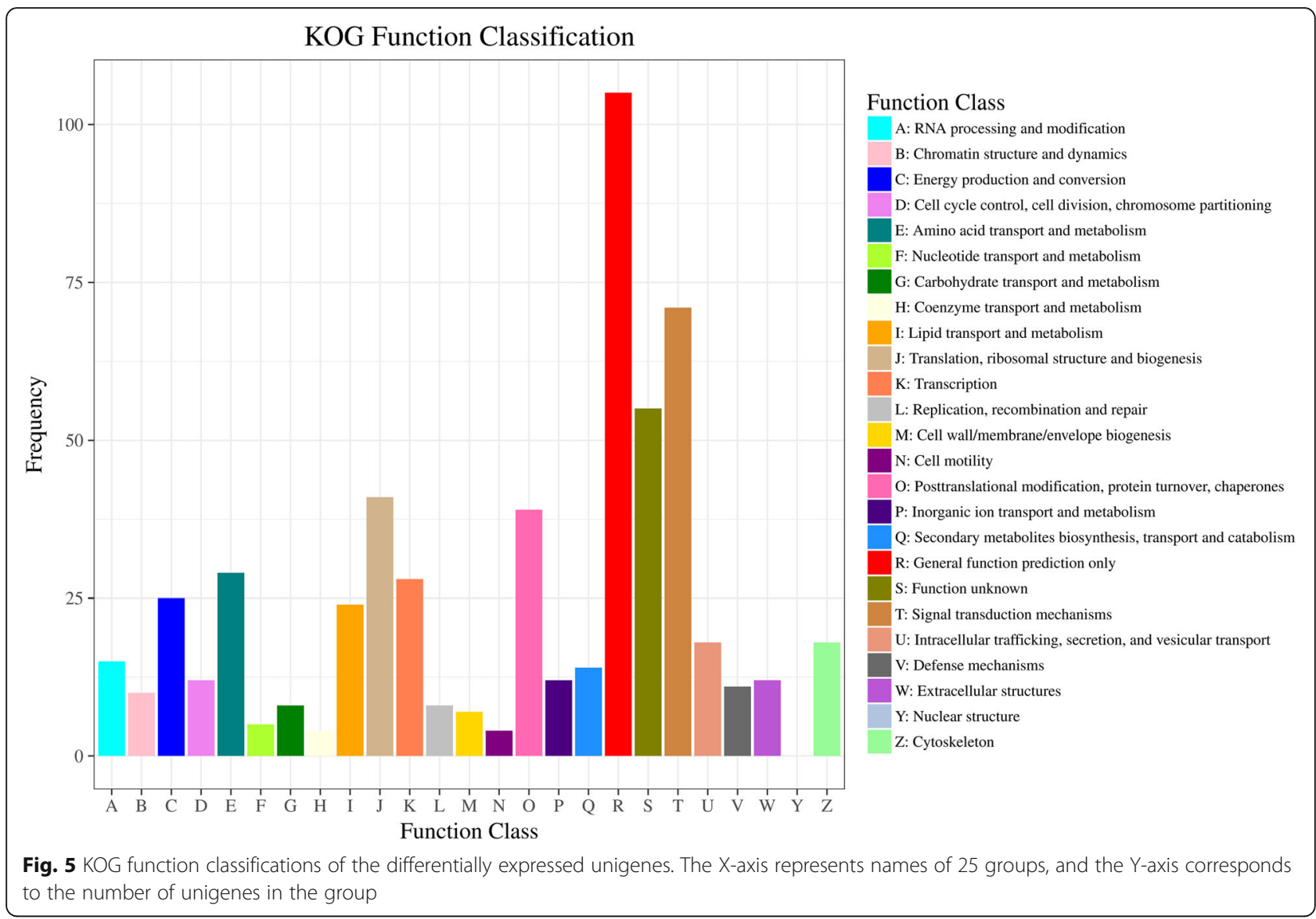

$2.539, \mathrm{P}$ value $=0.18632)$, one glycerol-3-phosphate acyltransferases (GPAT) (Accession no. TC004512) (Fold change: 1.59; ANOVA, $\mathrm{df}_{1,4}, \mathrm{~F}=8.092, P$ value $=$ 0.04665), four trehalase (TRE) genes responsible for trehalose hydrolysis (Accession no. TC006698, LOC659620, TC004791 and TC006697) (Fold change: 1.86, 1.48, 1.60 and 1.86; ANOVA, $\mathrm{df}_{1,4}, \mathrm{~F}=9.491,0.699,25.660$ and 9.491, $P$ value $=0.03690,0.45001,0.00715$ and 0.03690 ), two genes involved in gluconeogenesis including pyruvate carboxylase (PC) (Accession no. TC032730) (Fold change: 1.73; ANOVA, $\mathrm{df}_{1,4}, \mathrm{~F}=19.919$, $\mathrm{P}$ value $\left.=0.01113\right)$ and phosphoenolpyruvate carboxykinase (PEPCK) (Accession no. TC009072) (Fold change: 1.23; ANOVA, $\mathrm{df}_{1,4}, \mathrm{~F}=1.491, \mathrm{P}$ value $=$ 0.28918 ) were significantly upregulated (Table 4). Interestingly, SREBP1(Accession no. TC007163) (Fold change: 1.93; ANOVA, $\mathrm{df}_{1,4}, \mathrm{~F}=9.490, \mathrm{P}$ value $=0.03691$ ), the master regulator of lipid homeostasis, and SREBP cleavageactivating protein (SCAP) (Accession no. TC013456) (Fold change: 1.75; ANOVA, $\mathrm{df}_{1,4}, \mathrm{~F}=10.483$, $\mathrm{P}$ value $=0.03174$ ), a central regulator of lipogenesis that controls the activity of SREBP [53] were also significantly upregulated (Table 4).

\section{Discussion}

In insects, the energy for growth and development is mainly derived from the storage and utilization of lipids and carbohydrates in specific tissues such as fat body, midgut and oenocytes [39]. TG is the master form of lipids stored in fat body and plays an important role in energy storage and release [63]. Meanwhile, glucose (monosaccharide) and trehalose (disaccharide) provide energy through glycolysis [48]. Given that AMPK activates ATP-generating pathways and inhibits energyconsuming processes under conditions of low energy status [60], the attenuation of AMPK signaling in insects may disrupt the energy balance in vivo. In this study, we found that the TG and glucose levels in dsTcAMPK $\alpha$ injected $T$. castaneum were significantly increased compared with dsEGFP-injected insects, while a decreased trehalose content was observed in dsTcAMPK $\alpha$-injected insects. These results were further confirmed by in vivo AICAR treatment, which resulted in the decreased TG and glucose levels and increased trehalose content. Similarly, AICAR-induced AMPK activation resulted in significantly decreased TG level in lean and obese rodents, in vivo [6]. In human HepG2 cells, the kinase-inactive AMPK $\alpha$ increased lipid content and prevent the metformin from decreasing lipid accumulation [74]. However, lower TG levels were observed in D. melanogaster with reduced AMPK function during fed conditions [27]. On the other hand, while activation of AMPK triggered a 
Table 3 DEGs involved in different functional categories of KOG database

\begin{tabular}{|c|c|c|c|c|}
\hline \multirow[t]{2}{*}{ Categories } & \multicolumn{2}{|c|}{ Up-regulated DEGs } & \multicolumn{2}{|c|}{ Down-regulated DEGs } \\
\hline & NO. & Partial gene description & NO. & Partial gene description \\
\hline Signal transduction mechanisms & 26 & $\begin{array}{l}\text { tyrosine-protein phosphatase; phorbol } \\
\text { ester/diacylglycerol-binding protein; } \\
\text { lachesin; arf-GAP; citron Rho-interacting } \\
\text { kinase; cyclic nucleotide-gated cation } \\
\text { channel; E3 ubiquitin; sortilin; lipid } \\
\text { transfer protein }\end{array}$ & 23 & $\begin{array}{l}\text { neurogenic locus protein; extensin; } \\
\text { SNF1A/AMP-activated protein kinase; } \\
\text { cGMP-dependent phosphodiesterase; } \\
\text { troponin C; sortilin; atrial natriuretic; } \\
\text { sensory neuron membrane protein; } \\
\text { regulator complex protein; tetra } \\
\text { phosphatase }\end{array}$ \\
\hline $\begin{array}{l}\text { Translation, ribosomal structure } \\
\text { and biogenesis }\end{array}$ & 1 & eukaryotic translation initiation factor & 42 & $\begin{array}{l}\text { ribosomal protein; exosome } \\
\text { complex component; ribonuclease; } \\
\text { H/ACA ribonucleoprotein; eukaryotic } \\
\text { translation initiation factor }\end{array}$ \\
\hline $\begin{array}{l}\text { Posttranslational modification, } \\
\text { protein turnover, chaperones }\end{array}$ & 7 & $\begin{array}{l}\text { papilin; heat shock protein 68a; } \\
\text { pregnancy zone protein; } \\
\text { fucosyltransferase; brain tumor } \\
\text { protein; E3 ubiquitin; }\end{array}$ & 35 & $\begin{array}{l}\text { mannosyltransferase; sulfotransferase; } \\
\text { GILT-like protein; heat shock protein } \\
\text { 23; ubiquitin; suppressor protein; } \\
\text { collagenase; glutathione S-transferase; } \\
\text { protein transport protein; NEDD8 }\end{array}$ \\
\hline Amino acid transport and metabolism & 4 & $\begin{array}{l}\text { hydroxylase; protease; transporter; } \\
\text { glucose dehydrogenase }\end{array}$ & 30 & $\begin{array}{l}\text { proteinase; Carboxypeptidase; } \\
\text { glucose dehydrogenase; trypsin }\end{array}$ \\
\hline Lipid transport and metabolism & 5 & $\begin{array}{l}\text { nose resistant to fluoxetine protein; } \\
\text { fatty acyl-CoA reductase; apolipophorins; } \\
\text { ATP-binding cassette; Fatty acid synthetase }\end{array}$ & 17 & $\begin{array}{l}\text { dehydrogenase/reductase; NADPH; } \\
\text { alpha-tocopherol; acyl-CoA-binding } \\
\text { protein; nose resistant to fluoxetine } \\
\text { protein; fatty acyl-CoA reductase; } \\
\text { desaturase; monooxygenase }\end{array}$ \\
\hline Energy production and conversion & 1 & titin isoform $\times 4$ & 23 & $\begin{array}{l}\text { cytochrome b-c1 complex; stunted; } \\
\text { ATP synthase; V-type proton ATPase; } \\
\text { NADH dehydrogenase; cytochrome } \\
\text { c oxidase; cytochrome b5; } \\
\text { acylphosphatase; }\end{array}$ \\
\hline $\begin{array}{l}\text { Secondary metabolites biosynthesis, } \\
\text { transport and catabolism }\end{array}$ & 5 & $\begin{array}{l}\text { fatty acyl-CoA reductase; cytochrome } \\
\text { P450s; multidrug resistance-associated } \\
\text { protein lethal }\end{array}$ & 12 & $\begin{array}{l}\text { dehydrogenase/reductase; NADPH; } \\
\text { laccase; fatty acyl-CoA reductase; } \\
\text { cytochrome P450s }\end{array}$ \\
\hline Carbohydrate transport and metabolism & 1 & mucin & 6 & $\begin{array}{l}\text { amylase; chitinase; lactoylglutathione } \\
\text { lyase; glycolipid transfer protein; } \\
\text { myrosinase; peritrophic matrix protein }\end{array}$ \\
\hline
\end{tabular}

reduction in glucose levels in vivo in mice [72], and increased hepatic glucose production was observed in AMPK $\alpha 2$ knockout mice [3], knockdown of hypothalamic AMPK activity in male Sprague-Dawley rats led to a significant suppression of glucose production [73]. These results indicate the complexity of the role of AMPK in the regulation of metabolic processes.

As an energy sensor that regulates cellular metabolism, AMPK not only has acute effects on metabolic enzymes by direct phosphorylation, but also shows long term action to change the transcriptional levels of metabolic proteins and enzymes. For example, activation of AMPK in liver and adipocytes can downregulate FAS activity and inhibit lipogenesis [36]. Activation of AMPK by 4-Hydroxyderricin and xanthoangelol downregulates GPAT in 3 T3-L1 cells [75], an enzyme necessary for triacylglycerol synthesis [66]. Similarly, in C. elegans, AAK-2 can inhibit fat synthesis under stress condition by downregulating lipid synthesis-related genes such as $\Delta 9$ fatty acid desaturases which can produce monounsaturated fatty acids to constitute TGs $[55,65]$. To investigate the downstream transcriptional pathways of AMPK in $T$. castaneum, the transcriptomes of dsTcAMPK $\alpha-$ injected and dsEGFP-injected larvae under normal conditions were compared. Global gene expression profiles of dsTcAMPK $\alpha$ group were distinct from dsEGFP group with 1184 DEGs. Of particular interest is the upregulation of genes involved in fatty acid and TG biosynthetic pathways, such as FAS, ACC and GPAT, whereas the relative expression level of brummer involved in TG hydrolysis [14] was dramatically downregulated. We also observed the upregulation of several carbohydrate metabolism-related genes, such as TRE, and two key enzymes in gluconeogenesis (de novo synthesis of glucose), PC and PEPCK $[16,26]$, in the dsTcAMPK $\alpha$-injected insects. The transcriptional changes of genes encoding 
Table 4 DEGs encoding metabolism related proteins and transcription factors/ co-activators from T. castaneum responding to dsTCAMPKa treatment

\begin{tabular}{|c|c|c|c|c|c|}
\hline Unigene name & padj & $\begin{array}{l}\text { Description } \\
\text { (blast) }\end{array}$ & $\begin{array}{l}\text { Length } \\
\text { (ORF bp) }\end{array}$ & $\begin{array}{l}\log _{2} \text { Ratio } \\
\text { Transcriptome }\end{array}$ & $\begin{array}{l}\log _{2} \text { Ratio } \\
\text { qRT-PCR }\end{array}$ \\
\hline \multicolumn{6}{|c|}{ Lipid metabolism } \\
\hline FAS1 & 0.038775298 & fatty acid synthase & 12,981 & 1.02 & 0.37 \\
\hline FAS2 & 0.056982009 & fatty acid synthase & 6522 & 1.76 & 0.71 \\
\hline FAS3 & 0.260213539 & fatty acid synthase & 7152 & 0.79 & 1.05 \\
\hline FAS4 & 0.425672932 & fatty acid synthase & 6630 & 0.63 & 1.16 \\
\hline FAS5 & 0.170696071 & fatty acid synthase & 6450 & 0.58 & 1.53 \\
\hline ACC & 0.186316184 & acetyl-CoA carboxylase & 7005 & 0.83 & 0.10 \\
\hline GPAT3 & 0.046646995 & glycerol-3-phosphate acyltransferases & 1440 & 0.67 & 1.51 \\
\hline Brummer & 1.60E-05 & triacylglycerol lipase & 1635 & -2.20 & -0.37 \\
\hline \multicolumn{6}{|c|}{ Carbohydrate metabolism } \\
\hline TRE1-1 & 0.036902117 & Trehalase1-1 & 1662 & 0.89 & 1.46 \\
\hline TRE1-3 & 0.450009964 & Trehalase1-3 & $>507$ & 0.56 & 0.58 \\
\hline TRE1-4 & 0.007152475 & Trehalase1-4 & 1812 & 0.68 & 0.59 \\
\hline TRE2 & 0.036902117 & Trehalase2 & 1647 & 0.89 & 1.61 \\
\hline \multicolumn{6}{|c|}{ Insulin signaling pathway } \\
\hline IRS1 & 0.018687502 & insulin receptor substrate & 2760 & 1.13 & 0.63 \\
\hline $\ln R 2$ & 0.004419643 & insulin-like receptor & 4185 & 1.09 & 0.23 \\
\hline PI3K & 3.37E-08 & phosphatidylinositol 4,5-bisphosphate 3-kinase & 3186 & 1.02 & 0.63 \\
\hline \multicolumn{6}{|c|}{ Transcription factor and co-activator } \\
\hline SCAP & 0.031742692 & sterol regulatory element binding protein cleavage-activating protein & 3783 & 0.81 & 1.12 \\
\hline SREBP1 & 0.036908768 & sterol regulatory element binding protein 1 & 3078 & 0.94 & 1.74 \\
\hline ChREBP & 0.000606393 & carbohydrate response-element-binding protein & 510 & 1.18 & 1.94 \\
\hline
\end{tabular}

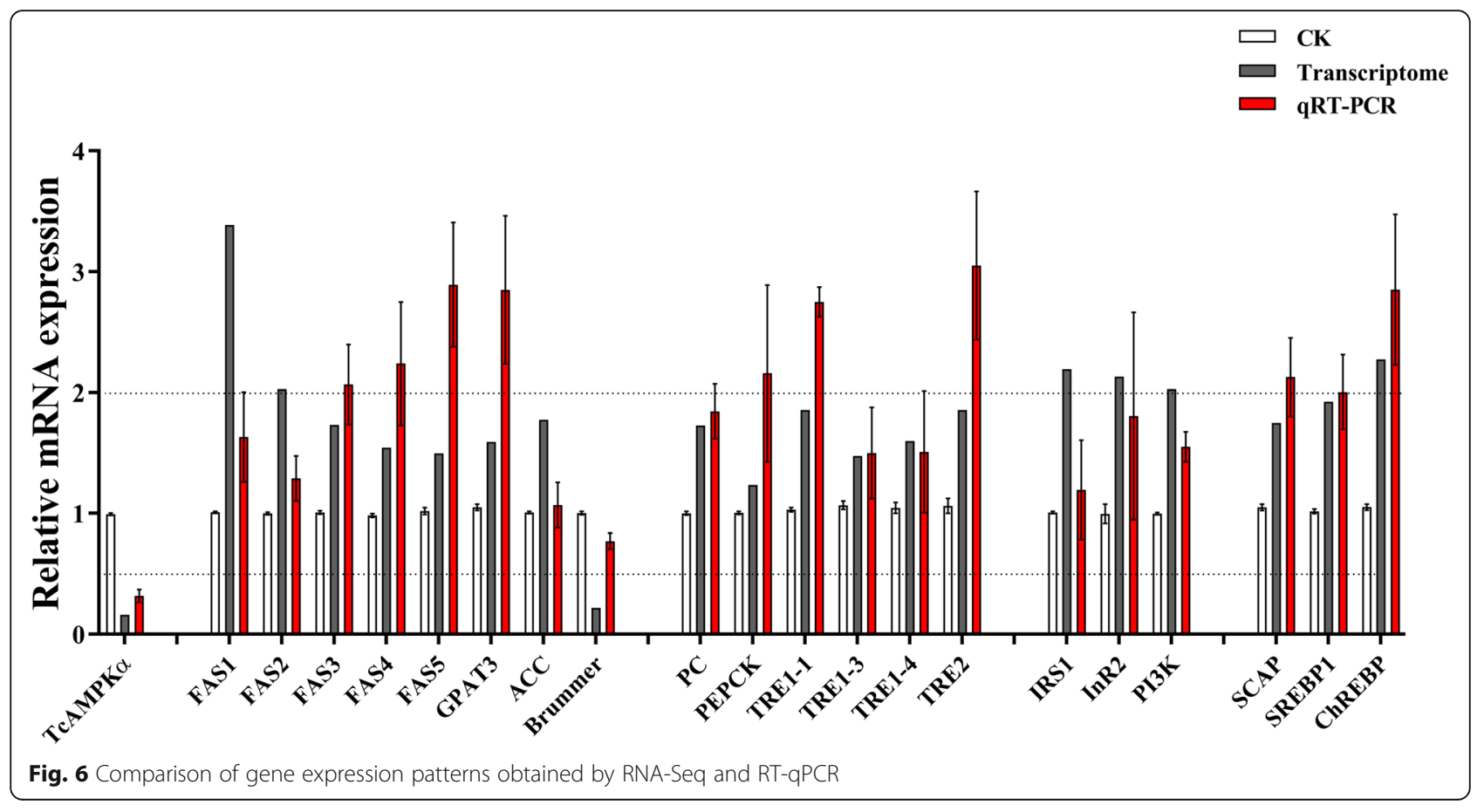


metabolism enzymes might contribute to the increased TG and glucose levels and decreased trehalose content in dsEGFP-injected beetles.

AMPK activation has been reported to cause a reduction in transcriptional activity of several metabolismrelated transcription factors. As a key transcription factor that regulates cellular lipogenesis in liver, skeletal muscle and adipose tissue, insulin-activated SREBP1 acts in synergy with glucose-senstive ChREBP, which mediates the response to dietary carbohydrates and is essential for regulating lipogenic gene expression [46]. AMPK-inhibited SREBP1 can block expression of some gluconeogenic and lipogenic genes, whereas SREBP1 overexpression can increase their transcription [12, 31, 54]. Activation of AMPK by metformin or an adenosine analogue suppresses the expression of SREBP1. In metformin-treated rats, hepatic expression of SREBP1 mRNAs and protein is reduced [76]. A recent study indicated that AMPK interacts with and directly phosphorylates SREBP1, suppresses SREBP1 cleavage and nuclear translocation, and represses SREBP1 target gene Fas expression in hepatocytes in response to metformin treatment, leading to reduced lipogenesis [34]. On the other hand, AMPK also phosphorylates Ser568 and reduce DNA binding capacity and promote nuclear exclusion of murine ChREBP $[28,29]$. Interestingly, the promotion of PEPCK expression is associated with increased expression of SREBP-1 and ChREBP in high free fatty acid (HFFA)-treated hepatocytes [32], and a recent study also revealed the role of ChREBP in gluconeogenesis [58]. In this study, SREBP1, ChREBP and SCAP were significantly upregulated in dsTcAMPK $\alpha$-injected insects, which in turn might modulated the expression of genes involved in lipid and carbohydrate metabolism.

IIS pathway was involved in the regulation of glucose and lipid metabolism (Saltie and Kahn 2001) [50]. In addition to the regulation of lipid synthesis, studies reveal expanding roles for SREBP1 in controlling pathways for insulin resistance [34], in which the pathological process involves a series of cascades, including defective activation of IRS and PI3K [22, 30, 59]. Overexpression of SREBP1 decreased Irs-1 mRNA levels in a dose-dependent manner, and SREBP1 knockdown led to an upregulation of IRS-1 levels [34]. Further luciferase reporter assay confirmed that Irs-1 promoter activity was repressed by SREBP1 overexpression [34]. However, in liver with Nonalcoholic fatty liver disease (NAFLD), IRS-1 expression was enhanced and correlated positively with SREBP1 expression. In contrast, IRS- 2 expression decreased by $50 \%$ and was not correlated with SREBP1 [31]. In sebocytes, insulin-like growth factor-1 (IGF-1) induces SREBP-1 expressions at both mRNA and protein levels in a PI3K-dependent manner, accompanied by an increase in the transcription of SREBP-1 target genes such as FAS [57]. Additionally, insulin-stimulated endogenous ChREBP expression was also observed in HepG2 and primary hamster hepatocytes (Sirek et al. 2009) [56]. In this study, we observed the upregulation of IIS-related DEGs like IRS1, InR2 and PI3K in dsTcAMPK $\alpha$-injected beetles, which might result in the upregulation of SREBP1 and ChREBP. Interestingly, it has been reported that knockdown in expression of insulin like peptide 2 (ILP2) caused a decrease in TRE mRNA levels in T. castaneum [71], suggesting the positive control of TRE transcription by IIS signaling. Further study is needed to clarify the mechanism of upregulation of IIS signaling in dsTcAMPK $\alpha$-injected insects.

\section{Conclusion}

This study confirmed that AMPK has an important role in the regulation of beetle metabolism. Specifically, our study showed that knockdown of AMPK causes alteration in expression levels of genes involved in lipid and carbohydrate metabolism as well as IIS signaling. Such investigations will help us understand the function of AMPK in transcriptional regulation of insect metabolism.

\section{Methods}

\section{Experimental insects}

The Georgia-1 (GA-1) strain of T. castaneum was reared at $30{ }^{\circ} \mathrm{C}$ and $50 \%$ relative humidity in $5 \%$ yeasted flour under standard conditions as described previously $[15,33]$.

\section{Double-strand RNA synthesis and injection}

Gene specific primers (Table S1) with T7 promoter were designed to synthesize the dsRNAs targeting nucleotides 844-1285 (442 bp) of the ORF region of the TcAMPKa using TranscriptAid ${ }^{\text {tw }}$ T7 High Yield Transcription Kit (Thermo Fisher Scientific, Waltham, MA, USA) according to the manufacturer's instructions. The synthesized dsRNAs were diluted in diethyl pyrocarbonate (DEPC)treated water with a concentration of $2 \mu \mathrm{g} / \mu \mathrm{L}$, and about $200 \mathrm{ng}$ of dsRNA in $200 \mathrm{~nL}$ IB was injected into 20-dayold larvae using a Nanoliter 2010 injector system (WPI, Sarasota, FL, USA) under a stereomicroscope. A total of 10 unsexed insect larvae were collected as a sample for RNA extraction at six- days post-injection. The dsEGFPinjected larvae (CK group) were set as controls in all injection experiments. Three biologically independent replicates were carried out with at least 100 insects $(\geq 200$ $\mathrm{mg}$ ) in each replicate.

\section{Triglyceride (TG) measurement}

Total TG levels were determined using the liquid TG (GPO-PAP) method [4]. Briefly, each replicate with 10 injected larvae were homogenized in $270 \mu \mathrm{L}$ of PBS $(0.1$ $\mathrm{mol} / \mathrm{L} \mathrm{PH} \mathrm{7.4)}$ and centrifuged at $2500 \mathrm{rpm}$ for $10 \mathrm{~min}$. The supernatant was collected, and the TG level was analyzed by using TG Assay Kit (catalogue no. A110-1, 
Jiancheng Bioengineering Institute, Nanjing, China) according to the manufacturer's instructions. Three independent biological replicates and four technical replicates were performed for every treatment.

\section{Glucose and trehalose measurement}

Total glucose levels were measured using glucose content assay kit (catalogue no. BC2500, Solarbio Science \& Technology, Beijing, China) according to the manufacturer's instructions. Briefly, 10 larvae on day 6 after injection of dsTcAMPK $\alpha$ or dsEGFP were weighed and homogenized in $0.3 \mathrm{~mL}$ double distilled water. The supernatant was collected after centrifugation at $8000 \mathrm{~g}$ for $10 \mathrm{~min}$ and used to quantify the level of glucose at $505 \mathrm{~nm}$ with Multiskan FC microplate reader (Thermo Fisher Scientific, Waltham, MA, USA). Three independent biological replicates and 4 technical replicates were performed for every treatment.

Total trehalose level was measured using Trehalose content detection kit (catalogue no. A149-1-1, Jiancheng Bioengineering Institute, Nanjing, China) according to the manufacturer's instructions. Six days after injection of dsTcAMPK $\alpha$ or dsEGFP, 10 larvae were homogenized in $0.3 \mathrm{~mL}$ extraction solution and incubated at room temperature for $45 \mathrm{~min}$. The supernatant was collected after centrifugation at $8000 \mathrm{~g}$ for $10 \mathrm{~min}$, and used to quantify the level of trehalose at $620 \mathrm{~nm}$ with Multiskan FC microplate reader (Thermo Fisher Scientific, Waltham, MA, USA). Three independent biological replicates and four technical replicates were performed for every treatment.

\section{AICAR treatment}

To investigate the effects of AMPK activation on lipids and carbohydrates metabolism, 20-day-old larvae were injected with $200 \mathrm{~nL}$ of $1.6 \mathrm{mg} / \mathrm{mL}$ AICAR or IB as control. AMPK could be activated immediately by AICAR treatment among a couple of hours [40]. The total amounts of TG, glucose and glucose were determined at one- hour post-injection.

\section{RNA extraction, library construction and sequencing} Total RNA was isolated from 10 larvae of dsTcAMPK $\alpha$ or dsEGFP group on the sixth day after injection using TRIzol Reagent (Invitrogen, USA), and digested by RNase-free DNase I (Takara, Dalian, China) to remove genomic DNA contaminants. To ensure the quality of the samples for transcriptome sequencing, concentration and integrity of RNA samples were checked using a Nanodrop ND-1000 spectrophotometer (NanoDrop Technologies, Wilmington, DE) and an Agilent Bioanalyzer 2100 (Agilent, Palo Alto, CA), respectively. The qualified RNA samples were used for mRNA preparation and cDNA library construction. Three independent biological replicates were performed for every treatment. cDNA libraries were sequenced as described by Meng et al. (2019) [41].

\section{Sequence annotation}

To ensure the accuracy of sequence alignment, raw reads were cleaned by removing adapter and primer sequences, reads with ambiguous nucleotides larger than $5 \%$ and lowquality reads. Clean reads were aligned to the reference genome of T. castaneum (Reference genome version: GCF 000002335.3_Tcas5.2_genomic.fna; Reference genome site: ftp://ftp.ncbi.nlm.nih.gov/genomes/all/GCF/000/002/335/ GCF_000002335.3_Tcas5.2/GCF_000002335.3_Tcas5.2_ genomic.fna.gz) [21] using HISAT2 (CCB, Johns Hopkins University, USA). Subsequently, the transcripts were subjected to blast against GO, KOG and KEGG databases. GO is an international standard classification system of gene function (Figure S1 and Table S2). KOG database is based on the phylogenetic relationship of bacteria, algae and eukaryotes (Table S2). The KEGG database provides a powerful tool to discover the pathways in which genes are involved (Figure S2). In addition, Nr, COG, Pfam, GO and Swiss-Prot databases were also used to annotate unigenes. The E-value threshold was set to $10^{-5}$.

\section{Differentially expressed genes analysis}

Transcript abundances were measured by FPKM [61]. Differential expression analysis of dsTcAMPK $\alpha$ and dsEGFP groups were performed using DESeq2 software [2]. Unigene with False Discovery Rate (FDR) values < 0.05 and fold change $\mid \log _{2}$ (treatment/control) $\mid>1$ were set as the threshold for DEGs. GO and KOG database annotations were further analyzed to understand the functions of DEGs in T. castaneum.

\section{Reverse transcription quantitative real-time polymerase chain reaction (RT-qPCR)}

To validate the DEGs from the RNA-sequencing, RTqPCR reactions were performed on the Bio-Rad CFX 96 Real-time PCR system using TB Green ${ }^{\text {Tx }}$ Premix Ex Taq ${ }^{\text {Tw }}$ (Takara, Dalian, China) and gene specific primers (Table S1). The stably expressed gene encoding ribosomal protein S3 (rps3, GenBank: CB335975) was used as a reference gene [5]. PCR conditions were set as an initial incubation of $95^{\circ} \mathrm{C}$ for $30 \mathrm{~s}, 40$ cycles of $95^{\circ} \mathrm{C}$ for $5 \mathrm{~s}$ and $60^{\circ} \mathrm{C}$ for $30 \mathrm{~s}$, and a final melting curve analysis was performed. The mRNA levels were normalized to reference gene with the $2^{-\triangle \Delta C T}$ method Livak and Schmittgen [35]. The means and standard errors (mean \pm SE) for each time point were obtained from the average of at least three biologically independent sample sets.

\section{Statistical analysis}

Statistical analysis was performed using Graphpad Prism 6 (GraphPad Software Inc., San Diego, USA) by one-way analysis of variance, followed by Tukey's Honestly Significant Difference test. All data are presented as the mean \pm SE. 


\section{Supplementary information}

Supplementary information accompanies this paper at https://doi.org/10. 1186/s12864-020-07070-3.

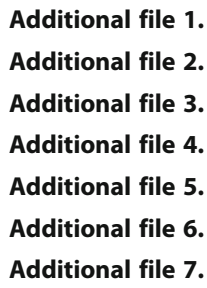

\section{Abbreviations}

ACC: acetyl-CoA carboxylase; AICAR: 5-Aminoimidazole-4-carboxamide1- $\beta$-Dribofuranoside; ATGL: adipocyte-triglyceride lipase; AMPK: AMP-activated protein kinase; CAMKK2: calcium/calmodulin-dependent kinase kinase 2; CHREBP: carbohydrate response element-binding protein; COG: Clusters of Orthologous Groups of proteins; DEGs: differentially expressed genes; DEPC: diethyl pyrocarbonate; FAS: fatty acid synthetase; FDR: False Discovery Rate; FPKM: Fragments Per Kilobase of transcript sequence per Million base pairs sequenced; GO: Gene Ontology; GPAT: glycerol-3-phosphate acyltransferases; HMGR: 3-hydroxy-3-methylglutaryl-CoA reductase; HSL: hormone-sensitive lipase; Hsps: heat shock proteins; IB: injection buffer; IIS: insulin/insulin-like growth factor signaling; ILP2: insulin like peptide 2; InR: insulin receptor; IRS-1: insulin receptor substrate-1; KEGG: Kyoto Encyclopedia of Genes and Genomes; KOG: EuKaryotic Orthologous Groups; LKB1: liver kinase B1; NAFLD: Nonalcoholic fatty liver disease; Nr: Nonredundant; PC: pyruvate carboxylase; PEPCK: phosphoenolpyruvate carboxykinase; Pfam: Protein family; PFK2: 6-phosphofructo-2-kinase PFKFB3: 6-phosphofructo-2-kinase/fructose-2,6-biphosphatase 3 PIK3: phosphatidylinositol 4,5-bisphosphate 3-kinase; RNAi: RNA interference; SCAP: SREBP cleavage-activating protein; SREBP1: sterol regulatory elementbinding protein 1; TG: triglyceride; TRE: trehalase

\section{Acknowledgements}

Not applicable.

\section{Authors' contributions}

JW conceived and designed research. HJ, NZ and CJ conducted experiments. $\mathrm{XM}, \mathrm{YZ}$ and $\mathrm{KQ}$ analyzed the data. HJ and JW wrote the manuscript. All authors read and approved the final manuscript.

\section{Funding}

This work was supported by the National Natural Science Foundation of China under grant nos. 31871974 and 31572000

The funding bodies played no role in the design of the study and collection, analysis, and interpretation of data and in writing the manuscript.

\section{Availability of data and materials}

All data generated or analyzed during this study are included in this article and its supplementary information files.

We have uploaded the raw data of our transcriptome sequencing to GEO database. The GEO accession number is GSE155634.

\section{Ethics approval and consent to participate}

Not applicable.

\section{Consent for publication}

Not applicable.

\section{Competing interests}

The authors declare that they have no competing interests.
Received: 28 April 2020 Accepted: 14 September 2020

Published online: 23 September 2020

\section{References}

1. Ahmadian M, Abbott MJ, Tang T, Hudak CS, Kim Y, Bruss M, Hellerstein MK, Lee HY, Samuel VT, Shulman GI. Desnutrin/ATGL is regulated by AMPK and is required for a brown adipose phenotype. Cell Metab. 2011;13:739-48.

2. Anders S, Huber W. Differential expression analysis for sequence count data. Genome Biol. 2010;11:R106.

3. Andreelli F, Foretz M, Knauf C, Cani PD, Perrin C, Iglesias MA, Pillot B, Bado A, Tronche F, Mithieux G. Liver adenosine monophosphate-activated kinasea2 catalytic subunit is a key target for the control of hepatic glucose production by adiponectin and leptin but not insulin. Endocrinology. 2006; 147:2432-41.

4. Annoni G, Botasso BM, Ciaci D, Donato MF, Tripodi A. Liquid triglycerides (GPO-PAP). Medi Diagnostic Italy J Labor Clin Med. 1982;9:115.

5. Arakane Y, Specht CA, Kramer KJ, Muthukrishnan S, Beeman RW. Chitin synthases are required for survival, fecundity and egg hatch in the red flour beetle, Tribolium castaneum. Insect Biochem Mol Biol. 2008;38:959-62.

6. Bergeron R, Previs SF, Cline GW, Perret P, Russell RR III, Young LH, Shulman $\mathrm{Gl}$. Effect of 5-aminoimidazole-4-carboxamide-1- $\beta$-d-ribofuranoside infusion on in vivo glucose and lipid metabolism in lean and obese Zucker rats. Diabetes. 2001;50:1076-82.

7. Cantó C, Auwerx J. AMP-activated protein kinase and its downstream transcriptional pathways. Cell Mol Life Sci. 2010;67:3407-23.

8. Carling D, Zammit VA, Hardie DG. A common bicyclic protein kinase cascade inactivates the regulatory enzymes of fatty acid and cholesterol biosynthesis. FEBS Lett. 1987;223:217-22.

9. Choi SL, Kim SJ, Lee KT, Kim J, Mu J, Birnbaum MJ, Kim SS, Ha J. The regulation of AMP-activated protein kinase by $\mathrm{H}_{2} \mathrm{O}_{2}$. Biochem Biophys Res Commun. 2001;287:92-7.

10. Chopra I, Li H, Wang H, Webster KA. Phosphorylation of the insulin receptor by AMP-activated protein kinase (AMPK) promotes ligand-independent activation of the insulin signalling pathway in rodent muscle. Diabetologia. 2012;55:783-94.

11. Fisher JS, Gao J, Han DH, Holloszy JO, Nolte LA. Activation of AMP kinase enhances sensitivity of muscle glucose transport to insulin. Am J Physiol Endocrinol Metab. 2002;282:E18-23.

12. Foretz M, Guichard C, Ferré P, Foufelle F. Sterol regulatory element binding protein-1C is a major mediator of insulin action on the hepatic expression of glucokinase and lipogenesis-related genes. Proc Natl Acad Sci U S A. 1999;96:12737-42.

13. Garcia D, Shaw RJ. AMPK: mechanisms of cellular energy sensing and restoration of metabolic balance. Mol Cell. 2017:66:789-800.

14. Grönke S, Mildner A, Fellert S, Tennagels N, Petry S, Müller G, Jäckle H, Kühnlein RP. Brummer lipase is an evolutionary conserved fat storage regulator in Drosophila. Cell Metab. 2005;1:323-30.

15. Haliscak JP, Beeman RW. Status of malathion resistance in five genera of beetles infesting farm-stored corn, wheat, and oats in the United States. J Econ Entomol. 1983;76:717-22.

16. Hanson RW, Reshef L. Regulation of phosphoenolpyruvate carboxykinase (GTP) gene expression. Annu Rev Biochem. 1997;66:581-611.

17. Hardie DG. AMP-activated/SNF1 protein kinases: conserved guardians of cellular energy. Nat Rev Mol Cell Biol. 2007;8:774.

18. Hardie DG, Carling D, Halford N. Roles of the Snf1/Rkin1/AMP-activated protein kinase family in the response to environmental and nutritional stress. Semin Cell Biol. 1994;5:409-16.

19. Hawley SA, Boudeau J, Reid JL, Mustard KJ, Udd L, Mäkelä TP, Alessi DR, Hardie DG. Complexes between the LKB1 tumor suppressor, STRADa/ $\beta$ and $\mathrm{MO} 25 \mathrm{a} / \mathrm{\beta}$ are upstream kinases in the AMP-activated protein kinase cascade. J Biol. 2003:2:28.

20. Hawley SA, Pan DA, Mustard KJ, Ross L, Bain J, Edelman AM, Frenguelli BG, Hardie DG. Calmodulin-dependent protein kinase kinase- $\beta$ is an alternative upstream kinase for AMP-activated protein kinase. Cell Metab. 2005;2:9-19.

21. Herndon N, Shelton J, Gerischer L, loannidis P, Ninova M, Dönitz J, et al. Enhanced genome assembly and a new official gene set for Tribolium castaneum. BMC Genomics. 2020;21:1-13.

22. Huang TJ, Verkhratsky A, Fernyhough P. Insulin enhances mitochondrial inner membrane potential and increases ATP levels through phosphoinositide 3-kinase in adult sensory neurons. Mol Cell Neurosci. 2005;28:42-54. 
23. Hurley RL, Anderson KA, Franzone JM, Kemp BE, Means AR, Witters LA. The $\mathrm{Ca}^{2+} /$ calmodulin-dependent protein kinase kinases are AMP-activated protein kinase kinases. J Biol Chem. 2005;280:29060-6.

24. Jakobsen SN, Hardie DG, Morrice N, Tornqvist HE. 5'-AMP-activated protein kinase phosphorylates IRS-1 on Ser-789 in mouse C2C12 myotubes in response to 5-aminoimidazole-4-carboxamide riboside. J Biol Chem. 2001; 276:46912-6.

25. Jiang H, Zhang N, Chen M, Meng X, Ji C, Ge H, Dong F, Miao L, Yang X, Xu $X$, Qian K, Wang J. Transcriptional and post-translational activation of AMPKa by oxidative, heat, and cold stresses in the red flour beetle, Tribolium castaneum. Cell Stress Chaperones. 2019;24:1079-89.

26. Jitrapakdee S, St Maurice M, Rayment I, Cleland WW, Wallace JC, Attwood PV. Structure, mechanism and regulation of pyruvate carboxylase. Biochem J. 2008:413:369-87

27. Johnson EC, Kazgan N, Bretz CA, Forsberg LJ, Hector CE, Worthen RJ, Onyenwoke R, Brenman JE. Altered metabolism and persistent starvation behaviors caused by reduced AMPK function in Drosophila. PLoS One. 2010; 5:e12799.

28. Kawaguchi T, Osatomi K, Yamashita H, Kabashima T, Uyeda K. Mechanism for fatty acid "sparing" effect on glucose-induced transcription regulation of carbohydrate-responsive element-binding protein by AMP-activated protein kinase. J Biol Chem. 2002;277:3829-35.

29. Kawaguchi T, Takenoshita M, Kabashima T, Uyeda K. Glucose and CAMP regulate the L-type pyruvate kinase gene by phosphorylation/ dephosphorylation of the carbohydrate response element binding protein. Proc Natl Acad Sci U S A. 2001;98:13710-5.

30. Kerouz NJ, Hörsch D, Pons S, Kahn CR. Differential regulation of insulin receptor substrates-1 and-2 (IRS-1 and IRS-2) and phosphatidylinositol 3 kinase isoforms in liver and muscle of the obese diabetic (Ob/Ob) mouse. J Clin Invest. 1997;100:3164-72

31. Kohjima M, Higuchi N, Kato M, Kotoh K, Yoshimoto T, Fujino T, Yada M, Yada R, Harada N, Enjoji M. SREBP-1C, regulated by the insulin and AMPK signaling pathways, plays a role in nonalcoholic fatty liver disease. Int. J. Mol. Med. 2008;21:507-11.

32. Kuo JJ, Chang HH, Tsai TH, Lee TY. Curcumin ameliorates mitochondrial dysfunction associated with inhibition of gluconeogenesis in free fatty acidmediated hepatic lipoapoptosis. Int J Mol Med. 2012;30:643-9.

33. Li B, Beeman RW, Park Y. Functions of duplicated genes encoding CCAP receptors in the red flour beetle, Tribolium castaneum. J Insect Physiol. 2011a;57:1190-7.

34. Li Y, Xu S, Mihaylova MM, Zheng B, Hou X, Jiang B, Park O, Luo Z, Lefai E, Shyy YJ. AMPK phosphorylates and inhibits SREBP activity to attenuate hepatic steatosis and atherosclerosis in diet-induced insulin-resistant mice. Cell Metab. 2011b;13:376-88

35. Livak KJ, Schmittgen TD. Analysis of relative gene expression data using real-time quantitative PCR and the $2^{-\Delta \Delta C T}$ method. Methods. 2011;25: 402-8.

36. Madsen A, Bozickovic O, Bjune Jl, Mellgren G, Sagen JV. Metformin inhibits hepatocellular glucose, lipid and cholesterol biosynthetic pathways by transcriptionally suppressing steroid receptor coactivator 2 (SRC-2). Sci Rep. 2015;5:16430.

37. Marsin AS, Bouzin C, Bertrand L, Hue L. The stimulation of glycolysis by hypoxia in activated monocytes is mediated by AMP-activated protein kinase and inducible 6-phosphofructo-2-kinase. J Biol Chem. 2002;277: 30778-83.

38. Marsin A, Bertrand L, Rider M, Deprez J, Beauloye C, Vincent MF, Van den Berghe G, Carling D, Hue L. Phosphorylation and activation of heart PFK-2 by AMPK has a role in the stimulation of glycolysis during ischaemia. Curr Biol. 2000;10:1247-55.

39. Martins GF, Serrão JE, Ramalho-OrtigãO JM, Pimenta PFP. Histochemical and ultrastructural studies of the mosquito Aedes aegypti fat body: effects of aging and diet type. Microsc Res Tech. 2011;74:1032-9.

40. Matsumoto Y, Sumiya E, Sugita T, Sekimizu K. An invertebrate hyperglycemic model for the identification of anti-diabetic drugs. PLoS One 2011;6:e18292

41. Meng X, Dong F, Qian K, Miao L, Yang X, Ge H, Wu Z, Wang J. Transcriptome analysis reveals global gene expression changes of Chilo suppressalis in response to sublethal dose of chlorantraniliprole. Chemosphere. 2019; 234: 648-57.

42. Muoio DM, Seefeld K, Witters LA, Coleman RA. AMP-activated kinase reciprocally regulates triacylglycerol synthesis and fatty acid oxidation in liver and muscle: evidence that sn-glycerol-3-phosphate acyltransferase is a novel target. Biochem J. 1999;338:783-91.

43. Musi N, Goodyear $\amalg$. Targeting the AMP-activated protein kinase for the treatment of type 2 diabetes. Curr Drug Targets Immune Endocr Metabol Disord. 2002;2:119-27.

44. Narbonne P, Roy R. Caenorhabditis elegans dauers need LKB1/AMPK to ration lipid reserves and ensure long-term survival. Nature. 2009;457:210.

45. Platara M, Ruiz A, Serrano R, Palomino A, Moreno F, Ariño J. The transcriptional response of the yeast $\mathrm{Na}^{+}$-ATPase ENA1 gene to alkaline stress involves three main signaling pathways. J Biol Chem. 2006;281:3663242.

46. Postic C, Ortega-Prieto P. Carbohydrate sensing through the transcription factor ChREBP. Front Genet. 2019:10:472.

47. Rasmussen BB, Winder WW. Effect of exercise intensity on skeletal muscle malonyl-CoA and acetyl-CoA carboxylase. J Appl Physiol. 1997;83:1104-9.

48. Reyes-DelaTorre A, Peña-Rangel MT, Riesgo-Escovar JR. Carbohydrate metabolism in Drosophila: reliance on the disaccharide trehalose. In: Chang C, editor. Carbohydrates-comprehensive studies on glycobiology and glycotechnology. Winchester: InTech. 2012; pp. 317-38.

49. Rider MH, Hussain N, Dilworth SM, Storey JM, Storey KB. AMP-activated protein kinase and metabolic regulation in cold-hardy insects. J Insect Physiol. 2011;57:1453-62.

50. Saltiel $A R$, Kahn CR. Insulin signalling and the regulation of glucose and lipid metabolism. Nature. 2001;414:799-806.

51. Sambandam N, Lopaschuk GD. AMP-activated protein kinase (AMPK) control of fatty acid and glucose metabolism in the ischemic heart. Prog Lipid Res. 2003:42:238-56.

52. Schulze SK, Kanwar R, Gölzenleuchter M, Therneau TM, Beutler AS. SERE: single-parameter quality control and sample comparison for RNA-Seq. BMC Genomics. 2012:13:524.

53. Shao W, Espenshade PJ. Sterol regulatory element-binding protein (SREBP) cleavage regulates Golgi-to-endoplasmic reticulum recycling of SREBP cleavage-activating protein (SCAP). J Biol Chem. 2014;289:7547-57.

54. Shimomura I, Bashmakov Y, Horton JD. Increased levels of nuclear SREBP-1C associated with fatty livers in two mouse models of diabetes mellitus. J Biol Chem. 1999:274:30028-32

55. Shin H, Lee H, Fejes AP, Baillie DL, Koo HS, Jones SJ. Gene expression profiling of oxidative stress response of $C$ elegans aging defective AMPK mutants using massively parallel transcriptome sequencing. BMC Res Notes. 2011:4:34

56. Sirek AS, Liu L, Naples M, Adeli K, Ng DS, Jin T. Insulin stimulates the expression of carbohydrate response element binding protein (ChREBP) by attenuating the repressive effect of Pit-1, Oct-1/Oct-2, and Unc-86 homeodomain protein octamer transcription factor-1. Endocrinology. 2009; 150:3483-92.

57. Smith TM, Gilliland K, Clawson GA, Thiboutot D. IGF-1 induces SREBP-1 expression and lipogenesis in SEB-1 sebocytes via activation of the phosphoinositide 3-kinase/Akt pathway. J Investig Dermatol Symp Proc. 2008:128:1286-93.

58. Tang Y, Wallace M, Sanchez-Gurmaches J, Hsiao WY, Li H, Lee PL, Vernia S, Metallo CM, Guertin DA. Adipose tissue mTORC2 regulates ChREBP-driven de novo lipogenesis and hepatic glucose metabolism. Nat Commun. 2016;7: $1-14$.

59. Taniguchi CM, Ueki K, Kahn CR. Complementary roles of IRS-1 and IRS-2 in the hepatic regulation of metabolism. J Clin Invest. 2005:115:718-27.

60. Towler MC, Hardie DG. AMP-activated protein kinase in metabolic control and insulin signaling. Circ Res. 2007;100:328-41.

61. Trapnell C, Williams BA, Pertea G, Mortazavi A, Kwan G, Van Baren MJ, Salzberg SL, Wold BJ, Pachter L. Transcript assembly and quantification by RNA Seq reveals unannotated transcripts and isoform switching during cell differentiation. Nat Biotechnol. 2010;28:511-5.

62. Uyeda K, Yamashita H, Kawaguchi T. Carbohydrate responsive elementbinding protein (ChREBP): a key regulator of glucose metabolism and fat storage. Biochem Pharmacol. 2002;63:2075-80.

63. Warnakula S, Hsieh J, Adeli K, Hussain MM, Tso P, Proctor SD. New insights into how the intestine can regulate lipid homeostasis and impact vascular disease: frontiers for new pharmaceutical therapies to lower cardiovascular disease risk. Can J Cardiol. 2011:27:183-91.

64. Watt MJ, Dzamko N, Thomas WG, Rose-John S, Ernst M, Carling D, Kemp BE, Febbraio MA, Steinberg GR. CNTF reverses obesity-induced insulin resistance by activating skeletal muscle AMPK. Nat Med. 2006;12:541. 
65. Watts JL. Fat synthesis and adiposity regulation in Caenorhabditis elegans. Trends Endocrinol Metab. 2009;20:58-65.

66. Wendel AA, Lewin TM, Coleman RA. Glycerol-3-phosphate acyltransferases: rate limiting enzymes of triacylglycerol biosynthesis. Biochim Biophys Acta Mol Cell Biol Lipids. 2009;1791:501-6.

67. Wilson WA, Hawley SA, Hardie DG. Glucose repression/derepression in budding yeast: SNF1 protein kinase is activated by phosphorylation under derepressing conditions, and this correlates with a high AMP: ATP ratio. Curr Biol. 1996;6:1426-34.

68. Winder W, Hardie D. Inactivation of acetyl-CoA carboxylase and activation of AMP-activated protein kinase in muscle during exercise. Am J Physiol Endocrinol Metab. 1996;270:E299-304.

69. Woods A, Dickerson K, Heath R, Hong SP, Momcilovic M, Johnstone SR Carlson M, Carling D. Ca ${ }^{2+} /$ calmodulin-dependent protein kinase kinase- $\beta$ acts upstream of AMP-activated protein kinase in mammalian cells. Cell Metab. 2005;2:21-33.

70. Woods A, Johnstone SR, Dickerson K, Leiper FC, Fryer LG, Neumann D, Schlattner U, Wallimann T, Carlson M, Carling D. LKB1 is the upstream kinase in the AMP-activated protein kinase cascade. Curr Biol. 2003;13:2004-8.

71. Xu J, Sheng Z, Palli SR. Juvenile hormone and insulin regulate trehalose homeostasis in the red flour beetle, Tribolium castaneum. PLoS Genet. 2013; 9:e1003535.

72. Yamauchi T, Kamon J, Minokoshi YA, Ito Y, Waki H, Uchida S, Yamashita S, Noda M, Kita S, Ueki K. Adiponectin stimulates glucose utilization and fattyacid oxidation by activating AMP-activated protein kinase. Nat. Med. 2002;8: 1288.

73. Yang CS, Lam CK, Chari M, Cheung GW, Kokorovic A, Gao S, Leclerc I, Rutter GA, Lam TK. Hypothalamic AMP-activated protein kinase regulates glucose production. Diabetes. 2010;59(2):2435-43.

74. Zang M, Zuccollo A, Hou X, Nagata D, Walsh K, Herscovitz H, Brecher P, Ruderman NB, Cohen RA. AMP-activated protein kinase is required for the lipid-lowering effect of metformin in insulin-resistant human HepG2 cells. $J$ Biol Chem. 2004:279:47898-905.

75. Zhang T, Sawada K, Yamamoto N, Ashida H. 4-Hydroxyderricin and xanthoangelol from Ashitaba (Angelica keiskei) suppress differentiation of preadiopocytes to adipocytes via AMPK and MAPK pathways. Mol Nutr Food Res. 2013:57:1729-40

76. Zhou G, Myers R, Li Y, Chen Y, Shen X, Fenyk-Melody J, Wu M, Ventre J, Doebber T, Fujii N. Role of AMP-activated protein kinase in mechanism of metformin action. J Clin Invest. 2001;108:1167-74.

\section{Publisher's Note}

Springer Nature remains neutral with regard to jurisdictional claims in published maps and institutional affiliations.

Ready to submit your research? Choose BMC and benefit from:

- fast, convenient online submission

- thorough peer review by experienced researchers in your field

- rapid publication on acceptance

- support for research data, including large and complex data types

- gold Open Access which fosters wider collaboration and increased citations

- maximum visibility for your research: over $100 \mathrm{M}$ website views per year

At $\mathrm{BMC}$, research is always in progress.

Learn more biomedcentral.com/submissions 